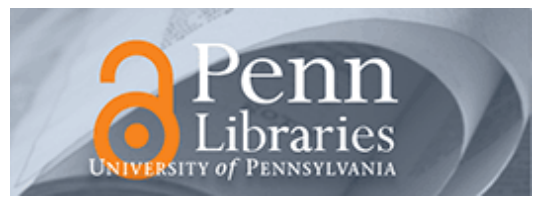

University of Pennsylvania ScholarlyCommons

\title{
Transforming the First Year of College for Students of Color
}

Laura W. Perna

University of Pennsylvania, Iperna@gse.upenn.edu

Michelle A. Cooper

Follow this and additional works at: https://repository.upenn.edu/gse_pubs

Part of the Education Economics Commons, and the Higher Education Commons

\section{Recommended Citation}

Perna, L. W., \& Cooper, M. A. (2005). Transforming the First Year of College for Students of Color. The Journal of Higher Education, 76 (4), 479-482. http://dx.doi.org/10.1353/jhe.2005.0030

Review of Transforming the First Year of College for Students of Color edited by L. I. Rendón, M.García, and D. Person. Columbia, S.C.: University of South Carolina, National Resource Center for the First-Year Experience and Students in Transition, 2004.

This paper is posted at ScholarlyCommons. https://repository.upenn.edu/gse_pubs/377

For more information, please contact repository@pobox.upenn.edu. 


\section{Transforming the First Year of College for Students of Color}

\section{Disciplines}

Education | Education Economics | Higher Education

\section{Comments}

Review of Transforming the First Year of College for Students of Color edited by L. I. Rendón, M.García, and D. Person. Columbia, S.C.: University of South Carolina, National Resource Center for the First-Year Experience and Students in Transition, 2004. 
instruction. Yet, despite these shortcomings, Cogs in the Classroom Factory is an excellent contribution to the literature, with rich insights into the details of graduate employee and contingent faculty organizing and work. It is essential reading for anyone interested in the restructuring of academic work, for its focus on the identities of employees and their unions addresses a key factor in organizing academic work in the 21 st century workplace.

\section{References}

Finkelstein, M., Schuster, J. H., and R. K. Seal. (1998). The New Academic Generation: A Profession in Transformation. Baltimore: Johns Hopkins University Press.

Hughes, E. C. (1958). Men and their Work. Glencoe, Illinois: Free Press.

Leslie, D. W., and J. M. Gappa. (1993). The Invisible Faculty: Improving the Status of Part-timers in Higher Education. San Francisco: Jossey-Bass.

Rhoades, G. (1998). Managed Professionals: Unionized Faculty and Restructuring Academic Labor. Albany, New York: State University of New York Press.

Transforming the First Year of College for Students of Color edited by L. I. Rendón, M.García, and D. Person.

Columbia, S.C.: University of South Carolina,

National Resource Center for the First-Year Experience and Students in Transition, 2004.

LAURA W. PERNA, University of Pennsylvania MICHELLE A. COOPER, University of Maryland, College Park

Campus leaders have traditionally based their understanding of student learning, development, and persistence on models that tend to ignore students' racial/ethnic, cultural, and social backgrounds. Transforming the First Year of College for Students of Color, a 12-chapter volume edited by Laura Rendón, Mildred García, and Dawn Person, is an important contribution to a recent line of research that addresses these omissions by offering approaches that explicitly consider the characteristics and perspectives of students of color. Designed primarily to inform practice (including teaching, learning, and campus life), this monograph describes the challenges that students of color encounter as they transition through the first-year of college and offers strategies for transforming the first-year experience to promote the academic and social integration of all students.

The 25 contributors to the volume provide a range of knowledge and orientations, as chapter authors include faculty in such fields as education, counseling, student development, psychology, and ethnic studies (Rendón, Person, Charles Colbert, Kenneth Gonzalez, Kevin Kinser, Wynetta Lee, Raechele Pope, Daryl Smith), a college president (Mildred García), administrators in such areas as academic affairs, enrollment management, institutional assessment, intergroup 
relations, multicultural affairs, and residential life (James Anderson, Mistalene Calleroz, Timothy Ecklund, Kris Ewing, Xiamei Feng, Romero Jalomo, Louis Olivas, Joseph Saggio, Corlisse Thomas, Jesús Treviño, and Xiaoyun Yang), and other experts (Teresa Miklitsch, Nana Osei-Kofi, Sandra Richards, Radhika Suresh, Dawn Tato). Reflecting this breadth of expertise, the volume effectively integrates and balances discussions of research findings and practical strategies. Collectively, the chapters (organized into four sections) present a cohesive vision for ensuring success for all students.

The three chapters in the first section, "identifying students of color and their unique needs," describe the need for transforming the first-year experience. This section identifies the range of forces that may restrict the success of students of color, including barriers related to economics (e.g., poverty), structures (e.g., inadequate resources in the high school attended; curricular tracking), and culture (e.g., first-generation college student; differences in cultural norms). In chapter three, Jalomo and Rendón argue that, for students of color (especially non-traditional students of color), transitioning to college involves three, often difficult, processes: geographic and cultural separation from the home community into the college community; validation of the ability to succeed in higher education; and involvement in campus academic and social activities.

The three chapters in the second section, "supporting students of color in the classroom and beyond," stress the ways college and university structures limit student success. Osi-Kofi, Richards, and Smith challenge faculty to move beyond superficial curricular changes to create inclusive teaching and learning environments. The authors raise questions for faculty to consider in their efforts to create inclusive classrooms and suggest that, among other characteristics, inclusive classrooms welcome voices of dissent, include diverse perspectives in course content, and incorporate a range of pedagogical techniques. Treviño and Ewing offer strategies for reducing barriers to student involvement, advocating structured inter-group interactions as a means for reducing conflict between groups and enhancing the campus climate for diversity. The authors also argue that campus administrators should reframe discussions of intra-group interactions to emphasize their beneficial effects, rather than simply characterizing such involvement as self-segregation.

The five chapters in section three, "working with specific populations," describe the retention-related needs and cultural conflicts of particular groups. While discussions of students of color typically include African Americans, Asian Americans, and Latinos, this monograph also addresses two other groups: American Indian/Alaska Natives and multiracial students. Together, the five chapters convincingly demonstrate that, despite some commonalities, students of color differ both across and within groups in terms of needs and challenges as well as patterns of adjustment and integration. Clearly a "one size fits all" approach will not adequately address the barriers to college success for all "students of color."

Comprised of one chapter by Rendón, the concluding section, appropriately titled "moving toward the future," synthesizes and builds on the other chapters in the volume. In part because of the strong foundation provided by prior chapters, this chapter persuasively argues for using a critical cultural perspective to guide efforts to transform the first-year and outlines the necessary components of a transformative first-year program. Rendón's central conclusion is that transforming the first-year experience requires moving beyond "simply offering 
services" to "include a social justice agenda that challenges existing structures and those they privilege, favoring democratic structural changes where power and privilege are shared among different constituencies" (p. 177).

The frameworks and strategies offered in this monograph offer promise for achieving the monograph's ultimate goal of "transforming the first year experience for students of color." However, fully achieving this transformation likely also requires explicit attention to an issue that is mentioned by several authors only in passing: finances. Specifically, efforts to transform the first year experience must include strategies for ensuring that students can pay the costs of attending college without engaging in behaviors that restrict their involvement in academic and social aspects of campus life.

Attention to financial resources is particularly important to transforming the experiences of students of color, since these groups are disproportionately from low-income families (Berkner \& Chavez, 1997). Both the costs of attending college and the types of financial aid that may offset college costs have greater influence on the college enrollment (Heller, 1997) and persistence (St. John, 2003) of students from low-income families than other students. Moreover, the majority of low-income undergraduates who are enrolled full-time, full-year have some amount of unmet financial need, regardless of whether they attend a public four-year institution (85\%), private non-profit four-year institution (88\%), or public two-year institution (93\%, Choy, 2000). ${ }^{1}$ At least in part because of financial need that is not met by financial aid, more than two-thirds of undergraduates who were enrolled full-time, full-year in 1995-96 worked while enrolled (Choy, 2000). Among those who worked, full-time low-income dependent undergraduates in 1995-96 averaged 19 hours of work per week at public and private non-profit four-year institutions and 23 hours per week at public two-year institutions (Choy, 2000). But, research suggests that working a high number of hours per week, even when on-campus, is negatively related to persistence (St. John, 2003). Although more research is required (St. John, 2003), current levels and patterns of college costs, financial aid, and employment likely restrict the success of students in two of the three transition processes that Jalomo and Rendón specify. First, students who are uncertain about their ability to pay college costs may not be able to "validate" their place on campus. Second, excessive work to pay college costs likely limits the time and energy available to become "involved" in campus life. Students who are unwilling to work or borrow the amounts necessary to pay college costs may have no choice but to reduce their enrollment intensity or leave the institution altogether.

Continued variation in degree attainment across racial/ethnic groups suggests that traditional strategies for addressing the needs and challenges of students of color are insufficient. The time to develop transformative approaches that address structural barriers to success is now, before the projected demographic changes in the composition of the traditional college-age population are fully realized. WICHE (2003) projects that the number and share of Whites among public high school graduates will decline through 2014, and that the greatest rates of growth will be among Hispanics and Asians. Effectively increasing the college success of all students requires changing institutional structures to acknowledge students' varied backgrounds. With the caveat that attention to finances is also required, Transforming the First Year of College for Students of Color should be used to inform these efforts. 
Notes

${ }^{1}$ Unmet financial need is defined by the federal government as the difference between the costs of attendance and the expected family contribution toward educational costs (Choy, 2000).

\section{References}

Berkner, L. \& Chavez, L. (1997). Access to postsecondary education for the 1992 high school graduates. Washington, DC: US Department of Education. (NCES 98-105)

Choy, S. (2000). Low-income students: Who they are and how they pay for their education. Washington, DC: U. S. Department of Education. (NCES 2000-169)

Heller, D.E. (1997). Student price response in higher education: An update to Leslie and Brinkman. Journal of Higher Education, 68(6), 624-651.

St. John, E. P. (2003). Refinancing the college dream: Access, equal opportunity and justice for taxpayers. Baltimore, MD: Johns Hopkins University Press.

Western Interstate Commission on Higher Education (2003). Knocking at the college door 2003: Projections of high school graduates by state, income and racelethnicity 1988-2018. Boulder, CO: Author.

University Leadership in Urban School Renewal edited by Nancy L. Zimpher and Kenneth R. Howey.

ACE/Praeger Series on Higher Education, 2004. 329 pp. \$42.95. ISBN 0-275-98095-2

PAMELA L. EDDY, Central Michigan University

Nancy Zimpher, president of the University of Cincinnati, and Kenneth Howey, research professor in teacher education at the University of Cincinnati, bring to their edited volume direct and practical experience regarding their book's topic of improving urban education via university collaborations. The intent of the book is to showcase how the actions of urban university presidents directly impacts and supports public school teachers and, ultimately, students. Contributors to the volume include 14 presidents whose colleges belong to the coalition of Great Cities' Universities (GCU). The 19 member institutions of the GCU serve almost 350,000 diverse students, providing a strong lever of change for improving the education of the nation's most vulnerable students.

Howey and Zimpher set the context for the book in their introductory chapter. They establish 15 priorities that identify ways in which presidents and chancellors can exert leadership to aid in improving K-12 education. Their framework groups priorities into three areas of foci: programmatic change, organizational change, and leadership and partnering. The extensive list provides a roadmap for university leaders interested in making change a reality in urban settings. Arguably, the concepts can apply to other change initiatives that 